\title{
Determination of Trace Elements in Sediments Samples by Using Neutron Activation Analysis
}

\author{
${ }^{1}$ Faculty of Health \& Life Sciences, INTI International University, Negeri Sembilan, Malaysia \\ ${ }^{2}$ Department of Physics, Faculty of Science, Universiti Putra Malaysia, Selangor, Malaysia \\ ${ }^{3}$ Department of Biology, Faculty of Science, Universiti Putra Malaysia, Selangor, Malaysia \\ Received - October 19, 2021; Revision - December 12, 2021; Accepted - January 14, 2022 \\ Available Online - February 28, 2022
}

Kumar Krishnan ${ }^{1}$, Elias B. Saion ${ }^{2}$, Yap CK ${ }^{3}$, Mee Yoke Chong ${ }^{1}$, A. S. Nadia ${ }^{1}$

DOI: http://dx.doi.org/10.18006/2022.10(1).21.31

\section{KEYWORDS \\ Enrichment \\ Geo-accumulation \\ Mangrove \\ Contamination factor \\ Pollution Load Index \\ Neutron activation}

\begin{abstract}
The Juru River is a highly industrialized, urbanized, and agricultural catchment. This study aimed to investigate trace elements in Juru mangrove sediments, including geochemical baselines and enrichment. Sediment was collected from the mangrove in Juru, Penang, Malaysia. A total of eight target elements was examined. Instrumentation activation analysis (INAA) was used to determine the concentration of $\mathrm{Fe}, \mathrm{V}, \mathrm{Cr}, \mathrm{Zn}$ and $\mathrm{Co}$. Atomic absorption spectrometry (AAS) was used to determine the concentration of elements that not detectable by INAA ( $\mathrm{Cd}, \mathrm{Pb}$, and $\mathrm{As})$. In both methods, validated reference material studies were used for validation of the methodology. Metal pollution was estimated using the Enrichment Factor (EF), Geoaccumulation Index (Igeo), Contamination Factor (CF), and Pollutant Load Index (PLI). The EF, Igeo, and CF ranges from 0.45-7.96, -2.18 - 1.95, and 0.33-5.83 respectively. The order of accumulation of the elemental concentration found was $\mathrm{Fe}>\mathrm{Zn}>\mathrm{Cr}>\mathrm{V}>\mathrm{Pb}$ $>\mathrm{As}>\mathrm{Co}>\mathrm{Cd}$. The computed mean value of PLI exceeds the unit (PLI > 1).
\end{abstract}

* Corresponding author

E-mail: kumar.krishnan@newinti.edu.my (Kumar Krishnan)

Peer review under responsibility of Journal of Experimental Biology and Agricultural Sciences.

Production and Hosting by Horizon Publisher India [HPI] (http://www.horizonpublisherindia.in/).

All rights reserved.
All the articles published by Journal of Experimental Biology and Agricultural Sciences are licensed under a Creative Commons Attribution-NonCommercial 4.0 International License Based on a work at www.jebas.org.

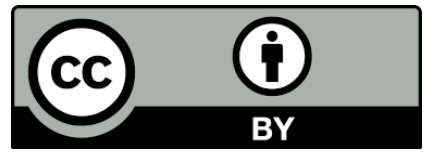




\section{Introduction}

Mangrove ecosystems have high-primary productivity and are coastal forests found in sheltered coasts, estuaries, riverbanks, and deltas in tropical countries. Mangroves are salt-tolerant evergreen trees that grow according to topography, climate, and water salinity. Instead of sand, the soft ground is mostly formed of clay and silt (Sasmito et al. 2020). The inputs of mangrove-derived organic matter into intertidal and river estuaries are important for a variety of fish and shellfish, including many commercial species, because nutrients are often adsorbed onto muddy sediment particles (Hatje et al. 2020). In recent years, the pressures due to increasing population in coastal areas, food production, economic activities, and urban development have caused the resources of the world's mangroves to be degraded (Friess et al. 2019). Growing industrialization and urbanization harmed the environment, particularly in mangrove areas around the world. Naturally occurring and anthropogenic factors trigger its component composition in the mangrove ecosystem (Zhang et al. 2009). Physical activities such as advection and convection, turbulence, diffusion, and others affect trace constituents, which are also influenced by biological processes such as ingestion, excretion, and biodegradation (Brügmann et al. 1999; Naser 2013) Contaminating mangroves and coastal ecosystems with trace and dangerous metals have become a serious threat to coastal ecosystems and humans who rely on marine resources for food and industry. Sediments are an important sink of a variety of pollutants, especially in estuarine ecosystems (Veettil et al. 2019). Metals such as zinc, copper, and chromium are crucial for the functioning of living organisms. However, over-consumption of these metals causes a variety of undesirable effects. Furthermore, due to the bioaccumulation and biomagnification of toxic metals, toxicity increases from low to high trophic levels in aquatic and terrestrial ecosystems will be most severely affected (Talukder et al. 2021; Yunus et al. 2020). Therefore, it is essential to monitor trace elements in sediment to increase knowledge of environmental processes. The elemental composition of nearby pollutant sources and other factors all influence the concentration of elements in sediment (Tiwari et al. 2020).

Many studies have been conducted to determine the level of micronutrients in Malaysian rivers, including Selangor (Kadhum et al. 2015), Sg. Terengganu, Terengganu (Sukri et al. 2018), Sg. Baleh in Sarawak (Chai et al. 2018), Sg. Langat Basin, Sg. Kepayang, Perak (Affandi and Ishak 2018), Sg. Linggi, Negeri Sembilan (Khalaf et al. 2018), Sg. Selangor, Selangor (Othman et al. 2018), Sg. Liwagu and Sg. Mansahaban in Sabah (Tair and Eduin 2018). However, until today there is a lack of information on the content of trace constituents in the mangrove sediments of Malaysia which are suppressed by various pollutants from upstream to downstream rivers.
The trace and toxic elements in sediments are analyzed with established analytical techniques which include alpha spectrometry, X-ray spectroscopy, Auger Electron Spectroscopy (ICP-AES), Atomic Absorption Spectroscopy (AAS), Inductively Coupled Plasma Mass Spectrometry (ICPMS), and instrument neutron activation analysis (INAA) (Tiwari et al. 2020; Diarra and Prasad 2020). However, each method presents advantages and disadvantages according to a particular task and purpose. The INAA is the most employed method for finding various types of ingredients due to its small sample size, chemical-free procedure, high sensitivity of low detection limit (LOD), concurrent multi-element detection (3040 elements), negligible matrix interference, samples changed to radioactive materials (Win 2004; Benarfa et al. 2020; Carvalho et al. 2019). In this work, two techniques, instrument Neutron Activation Analytical Instrumentation (INAA) and Atomic Absorption Spectrometry (AAS) were used. The AAS method was used for elements not sensitive to the INAA method. The sensitivity (10 to $30 \mathrm{mg} / \mathrm{sample}$ ), accuracy, and precision are of the same order for the two techniques and the choice can only be made depending on the urgency or convenience.

Determination of the concentrations of elements in the sediment of mangrove areas are among the first steps in the quantification of the natural and anthropogenic effects on mangrove ecosystems. A high level of contamination can cause hazardous effects on the ecosystem. Thus, the objective of this study is to provide important information on the ecological risk from the mangrove environment by evaluating enrichment factors, contamination factor, pollution load index and the geo-accumulation index. The INAA approach is used to determine the concentration of multi-trace elements in sediments in this work. Alternative method (AAS) was used for those elements not detectable in INAA.

\section{Materials and Methods}

\subsection{Study sites and samples collection}

Sediment samples were collected from the mangrove along the Juru River in Penang, Malaysia, as depicted in Figure 1. The sampling was carried out in January 2017 to detect hazardous substances at a trace level of mangrove of Juru River which is roughly a $12 \mathrm{~km}$ drive south of Butterworth. The Juru River, 7.95 $\mathrm{km}$ in length, flows from Bukit Minyak in the west to the South China Sea. The Juru River also crosses the North-South route, which extends $144.9 \mathrm{~km}$ between Ipoh and Alor Setar. The Permatang Rawa River and the Rambai River are two rivers that flow into the upper reaches of the Juru River. The Juru River is a lifeline for Kuala Sungai Juru, where the majority of the residents of Bukit Minyak are fishermen who rely heavily on fishing for their living. Furthermore, the Bukit Minyak area is famous for its 


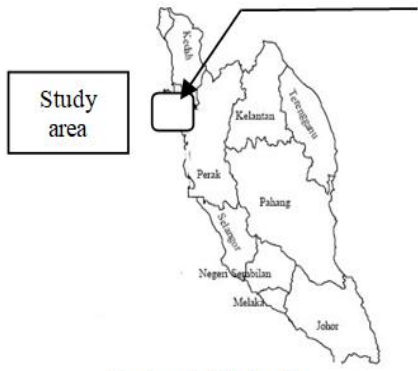

Peninsular Malaysia

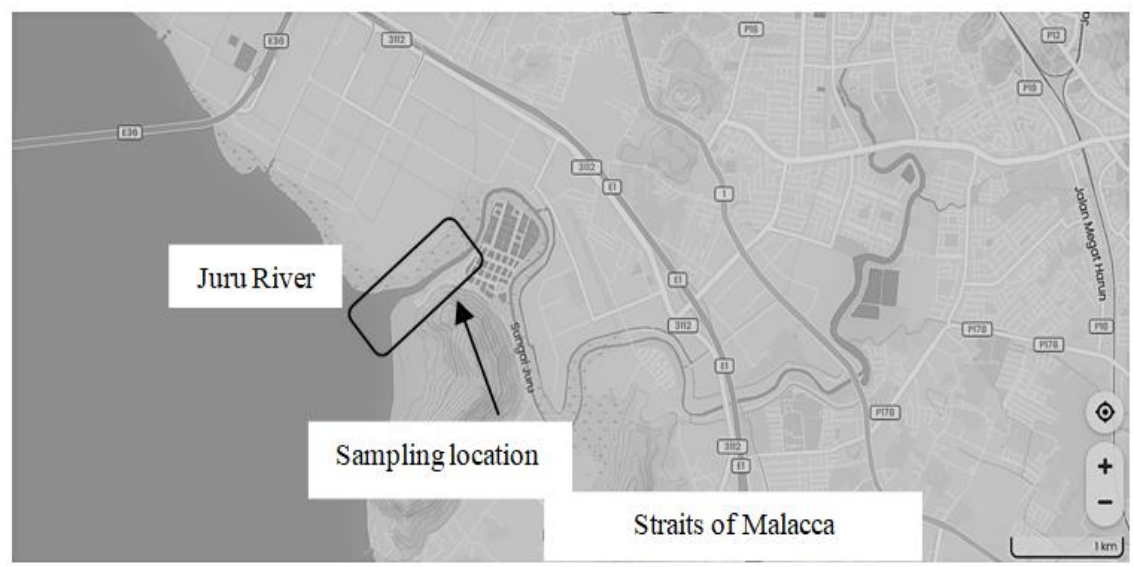

Straits of Malacca

Figure 1 Map showing the sampling site mangrove area along Juru river, Penang, Malaysia

cockle-breeding sector (industrialization). Before the industrial activities, the Juru River was free of pollution and its water was crystal clear. However, since 1970, the environmental landscape has changed as a result of industrial and building projects, as well as human settlements along the Juru River's riverbanks.

For uniformity and to be more typical of the sampling location, fifty sediment samples were collected and mixed. Sediment samples within range of 3.0-5.0 m adjacent to each other and approximately depth $5.0 \mathrm{~cm}$ were collected from the intertidal muddy region in the Jura mangrove area by using a pre-cleaned plastic scoop (Kumar et al. 2014; Yap et al. 2002). The collected surface sediment samples were placed in re-sealable polyethylene plastic bags labeled and held in an icebox at $4^{\circ} \mathrm{C}$. For moisture removal, surface sediments were dried in an $80^{\circ} \mathrm{C}$ oven for at least 72 hours on an oven-dry weight. After being crushed in an agate mortar with an agate pestle, the powdered form of sediments was sifted through a $63 \mu \mathrm{m}$ stainless steel aperture. The samples were stored in plastic pillboxes after being forcefully shaken (Ashraf et al. 2016; Wang et al. 2010; Rezaee et al. 2011).

\subsection{Chemical measurement}

The powdered samples were divided into four subsamples of approximately $150 \mathrm{mg}$ and $200 \mathrm{mg}$ and stored separately in heatsealed polyethylene vials for short and long radiation respectively. The half-lives and gamma energies of the radionuclides were used to identify them, and the element concentrations were determined using a comparative method (Kumar et al. 2014; Benarfa et al. 2020). The standard reference materials SRM (IAEA-Soil-7, SL-1 (Lake Sediment) were used as a multi-element comparator. For quality assurance purposes, blank samples, standard reference material, IAEA-Soil-7, and IAEA-SL-1 were irradiated together in a pneumatic transport facility at the research reactor operated at 750 $\mathrm{kW}$ (MINT TRIGA) with thermal neutron flux of $4.0 \times 10^{12} \mathrm{~cm}^{-2} \mathrm{~s}^{-1}$.
The samples were radiated for 1 minute and counted for 5 and 20 minutes after a cooling time of 20 minutes and 24 hours respectively during short radiation. For long radiation, the samples were irradiated for 6 hours and counted for 1hour after a cooling time of 3-4 and 21-28 days respectively. Counting of radiated samples was performed by using calibrated high-resolution HPGe detector. Distance between detector and sample was maintained approximately at $12 \mathrm{~cm}$ (short radiation) and $2 \mathrm{~cm}$ (long radiation). Specific energy of delayed gamma rays was used to identify the elements present in the sample and their concentration. The efficiency of the gamma spectroscopy system was calibrated with an energy range of $60-2 \mathrm{MeV}$ under the same geochemical configurations by using ${ }^{133} \mathrm{Ba},{ }^{60} \mathrm{Co},{ }^{57} \mathrm{Co}$, ${ }^{137} \mathrm{Cs},{ }^{54} \mathrm{Mn}$, and ${ }^{241} \mathrm{Am}$ standard point sources. All the counting was performed under the condition with a dead time lower than $10 \%$ (Kumar et al. 2014).

Approximately $500 \mathrm{mg}$ of powdered sediment sample was digested in ratio 4:1 of nitric acid and perchloric acid (BDH Analar grade). All the digestion tubes were placed into a digestion block at $40{ }^{\circ} \mathrm{C}$ for the first hour and then were completely digested approximately at $140{ }^{\circ} \mathrm{C}$ for at least 3 hours (Yap et al. 2002). $40 \mathrm{~mL}$ of double distilled water was used to dilute the resulting solution. The solution was then filtered out through a Whatman TM No. 1 filter paper Cat No 1001090 (diameter: $90 \mathrm{~mm}$ ) into a polyethylene container. A Perkin Elmer Model Analyst 800 and an air-acetylene atomic absorption spectrophotometer (AAS) were used to determine the concentrations of the elements. All the samples were analyzed in three replicates (Yap et al. 2002).

\subsection{Heavy metals enrichment and data treatment}

Several indexes including the enrichment factor, contamination factor, geo-accumulation index, and pollution load index were considered to assess the metal status for the sampled sediments. 


\subsubsection{Enrichment Factor (EF)}

The enrichment factor is one of the most useful methods for determining if anthropogenic contamination exists based on the computation of the normalization of each element concentration to $\mathrm{Fe}$ or Al. The significance of anthropogenic metal inputs was analyzed by enrichment factor (EF) (Zoller et al. 1974) and can be assessed by using the equation below:

$$
E F_{\text {metal }}=\frac{\left(\frac{M_{\text {exp }}}{F e_{\text {exp }}}\right)_{\text {sample }}}{\left(\frac{M_{\text {ref }}}{F e_{\text {ref }}}\right)_{\text {shale }}}
$$

Where $\mathrm{M}_{\text {ref }}$ or $\mathrm{Fe}_{\text {ref }}$ refers to a common abundant element in the average shale, while $\mathrm{M}_{\exp }$ or $\mathrm{Fe}_{\exp }$ refers to element concentration in the experimental sample (Mucha et al. 2003) (Table 1).

\subsubsection{Geo-accumulation Index (Igeo)}

Muller (1969) developed the Geoaccumulation index (Igeo), which is one of the most dependable indexes for calculating a system's contamination state. Based on the Geoaccumulation index (Igeo), the degree of metal pollution can be divided into seven enrichment classes as given in Table 2. Geo-accumulation index is calculated by the following equation:

$$
I_{\text {geo }}=\log _{2}\left[\frac{c_{n}}{1.5 \times B_{n}}\right]
$$

sediment samples and its baseline value, respectively. Factor 1.5 is used to remove the effect of background value changes that could be attributed to lithology variations in the sediments (Turekian and Wedepohl 1961; Stoffers et al. 1986).

\subsubsection{Contamination Factor $(\mathrm{CF})$}

Contamination Factor (CF) suggested by Hakanson (1980) and requires at least five surficial sediment samples which are averaged to produce a mean pollutant concentration and then compared with baseline pristine reference level (Abrahim et al. 2008). The contamination Factor is calculated by the following equation:

$$
C F=\frac{C_{\text {sample }}}{C_{\text {background }}}
$$

Where $C_{\text {sample }}$ is the metal concentration and $C_{\text {background }}$ represents the mean background value of the metal in sediment (Table 3 ).

\subsubsection{Pollution load index}

The pollution load index (PLI) was proposed by Tomlinson et al. (1980). PLI values indicate heavy metal loads near the background level or define as no pollution if the value is lower than one, while the values greater than one indicate soil pollution or contamination (Cabrera et al. 1999). PLI is calculated by the following equation:

$$
P L I=\sqrt[n]{C F_{1} \times C F_{2} \times C F_{3} \times \ldots . C F_{n}}
$$

Where $C_{n}$ and $B_{n}$ refer to the element's concentration in the Where CF is the contamination factor; $n$, number of metals (Table 4).

\begin{tabular}{|c|c|c|c|}
\hline Index & Classification & Sediment pollution status & Reference \\
\hline \multirow{7}{*}{ Igeo } & $<0$ & Unpolluted & \multirow{7}{*}{ Wang et al. 2015} \\
\hline & $0-1$ & Unpolluted to moderately polluted & \\
\hline & $1-2$ & moderately polluted & \\
\hline & $2-3$ & moderately to strongly & \\
\hline & $3-4$ & Strongly & \\
\hline & $4-5$ & strongly to extremely strongly & \\
\hline & $>5$ & extremely polluted & \\
\hline
\end{tabular}

Table 1 EF classification and sediment contamination status

\begin{tabular}{|ccc} 
Index & Classification & Sediment enrichment status \\
\cline { 2 - 3 } & $\leq 2$ & Low enrichment \\
\cline { 2 - 3 } & $2-5$ & Moderate enrichment \\
\hline & $5-20$ & High enrichment \\
\hline & $20-40$ & Dery high enrichment \\
\hline
\end{tabular}

Table 2 Igeo classification of the polluted samples

Journal of Experimental Biology and Agricultural Sciences http://www.jebas.org 
Table 3 CF classification and sediment contamination status

\begin{tabular}{|cccc|}
\hline Index & Classification & Sediment contanination status & Reference \\
\cline { 2 - 3 } & $<1$ & low contamination & Nasr et al. 2006 \\
\cline { 2 - 3 } & $1-3$ & moderate contamination & \\
\hline
\end{tabular}

Table 4 PLI classification and sediment contamination status

\begin{tabular}{|cccc|}
\hline Index & Classification & Sediment pollution status & Reference \\
\cline { 2 - 3 } & $<1$ & no pollution & Zarei et al. 2014 \\
\cline { 2 - 3 } & $1-2$ & moderate pollution & heavy pollution \\
\cline { 2 - 3 } & $2-3$ & extremely heavy pollution & \\
\hline
\end{tabular}

Table 5 The analysis of the standard reference material and comparison with certified values of SL- 1 and Soil-7(in $\mathrm{mg} / \mathrm{kg}$ )

\begin{tabular}{|ccccc|}
\hline Elements & Standard Value & Measured Value & Recovery (\%) & z-score \\
\hline $\mathrm{Fe}$ & $67400 \pm 1700$ & $67939 \pm 1332$ & 101 & -25 \\
\hline $\mathrm{Cr}$ & $104 \pm 9$ & $86 \pm 6$ & 83 & -0.44 \\
\hline $\mathrm{Pb}$ & $60 \pm 8$ & $49 \pm 5$ & 82 & -0.33 \\
\hline $\mathrm{V}$ & $170 \pm 15$ & $157.5 \pm 21.4$ & 93 & -0.03 \\
\hline $\mathrm{Zn}$ & $223 \pm 10$ & $247 \pm 17$ & 111 & -0.08 \\
\hline $\mathrm{As}$ & $27.6 \pm 2.9$ & $25.5 \pm 4.2$ & 103 & 0.06 \\
\hline $\mathrm{Co}$ & $19.8 \pm 1.5$ & $20.4 \pm 2.9$ & 123 & 0.31 \\
\hline $\mathrm{Cd}$ & $1.3 \pm 0.8$ & $1.6 \pm 0.4$ & & 0.06 \\
\hline
\end{tabular}

\subsection{Statistical analysis}

The $Z$-test was used to assess the precision and accuracy of the analytical processes used. The standardized difference $Z$ is calculated by taking into account the uncertainty in the SRM measured results as well as the uncertainty in the certified value to determine the analytical method's accuracy. The $Z$-test data is defined by:

$$
Z=\frac{c_{m}-c_{r e f}}{\sqrt{\sigma_{m}^{2}+\sigma_{r e f}^{2}}}
$$

Where $c_{\mathrm{m}}$ and $c_{\text {ref }}$ referred to measured and reference values of $\mathrm{SRM}, \sigma_{\mathrm{m}}$, and $\sigma_{\mathrm{ref}}$ are the standard deviation of measured and the reference value of SRM. If the value of Z-test $<|3|$, it shows that the results of the analysis of the SRM should be in the $99 \%$ confidence interval of the certified value. If the $Z$-test value is $<|3|$, the results of the SRM analysis should be within the 99 percent confidence interval of the certified value (Alnour et al. 2011, Alfian et al. 2020).

\section{Results and Discussion}

The quality and validity of the analytical method were checked with standard reference material SRM IAEA-Soil-7 and SL-1. Analytical results of the standard reference material and measured values (concentrations and its standard deviation) of IAEA soil-7 and SL-1 are shown in Table 5. The recoveries between the standard reference material and measured are within the range of acceptable (82-123\%) as shown in Table 5.

As shown in Table 5, the Z-test scores calculated by the analysis technique for all elements are within the acceptable range of -3 to +3 . It's worth noting that the measured SRM values were randomly distributed (above and below) to the certified levels, indicating that the analytical procedure did not make any systematic errors. The correlation coefficient of the linear regression between the 
determined concentrations of IAEA SRM Soiil-7 and SL-1 with those certified values was 0.9997 .

The INAA and alternative technique, AAS were used to identify and quantify a total of eight elements in sediments. Iron $(\mathrm{Fe})$ was the most abundant harmful element in seawater at trace levels, while cadmium (Cd) was the least abundant. Overall, target element abundance was found to be in the following sequence in sediments: $\mathrm{Fe}>\mathrm{Zn}>\mathrm{Cr}>\mathrm{V}>\mathrm{Pb}>\mathrm{As}>\mathrm{Co}>\mathrm{Cd}$. The composition of natural sediments and their anthropogenic sources around the sampling site may determine the order of abundance of the compounds. The levels of target hazardous elements observed in sediments from the Juru River in Malaysia (the current study) were comparable to data from other sections of the surface sediments collected from Kerteh mangrove forest where the average concentration of $\mathrm{Co}(8.91 \mu \mathrm{g} / \mathrm{g}), \mathrm{Cu}(29.0 \mu \mathrm{g} / \mathrm{g}), \mathrm{Pb}(11.7$ $\mu \mathrm{g} / \mathrm{g}), \mathrm{Zn}(22.3 \mu \mathrm{g} / \mathrm{g})$ and $\mathrm{Cr}(13.2 \mu \mathrm{g} / \mathrm{g})$ (Yunus and Chuan 2008) and Tanjung Lumpur mangrove forest the average concentrations of $\mathrm{Pb}, \mathrm{Cu}, \mathrm{Co}$, and $\mathrm{Mn}$ were $44.41 \mu \mathrm{g} / \mathrm{g}, 32.79$ $\mu \mathrm{g} / \mathrm{g}, 5.79 \mu \mathrm{g} / \mathrm{g}$ and $117.73 \mu \mathrm{g} / \mathrm{g}$ respectively (Yunus et al. 2011). As shown in Table 6, the mean concentration of trace elements of the study area is about the same as other studies except for $\operatorname{Co}(8.23 \mathrm{mg} / \mathrm{kg})$ which is much lower compared with the concentration of Co $(276 \mathrm{mg} / \mathrm{kg})$ from Badovci Lake (Kosovo) (Malsiu et al. 2020). Relative to the USEPA guidelines (PEL Indicators), the concentration of trace element $\mathrm{Zn}$ and $\mathrm{Pb}$ in the Juru river were much higher than the USEPA limit (USEPA 1994).

Table 6 The concentrations of trace elements (in $\mathrm{mg} / \mathrm{kg}$ )

\begin{tabular}{|ccccccc|}
\hline Element & Minimum & Maximum & Average & Standard deviation & Other studies & Maximum permissible limit \\
\hline $\mathrm{Fe}$ & 33405 & 37232 & 34579 & 1797 & $35900^{\mathrm{a}}$ & - \\
\hline $\mathrm{Cr}$ & 78.85 & 89.04 & 82.21 & 4.62 & $62.8^{\mathrm{a}}$ & $160^{*}$ \\
\hline $\mathrm{Pb}$ & 27.64 & 45.25 & 34.52 & 9.41 & $\begin{array}{c}100.94^{\mathrm{a}} \\
14.2-79.28^{\mathrm{b}}\end{array}$ & $8.1^{*}$ \\
\hline $\mathrm{V}$ & 69.94 & 87.72 & 77.13 & 8.71 & $88.2^{\mathrm{d}}$ & - \\
\hline $\mathrm{Zn}$ & 335.24 & 360.71 & 348.10 & 11.44 & $\begin{array}{c}273.29^{\mathrm{a}} \\
168.08-682.31^{\mathrm{b}}\end{array}$ & $81.0^{*}$ \\
\hline $\mathrm{As}$ & 9.15 & 11.47 & 10.50 & 0.98 & $11.2^{\mathrm{c}}$ & $15.0^{*}$ \\
\hline $\mathrm{Co}$ & 7.70 & 8.89 & 8.23 & 0.49 & $276^{\mathrm{d}}$ & $23.0^{* *}$ \\
\hline $\mathrm{Cd}$ & 0.572 & 0.696 & 0.639 & 0.063 & 4.713 & $38.0^{*}$ \\
\hline
\end{tabular}

${ }^{\mathrm{a}}$ Chen et al. 2016; ${ }^{\mathrm{b}}$ Ghannem et al. 2016; ${ }^{\mathrm{c}} \mathrm{Li}$ et al. 2008; ${ }^{\mathrm{d}}$ Avni Malsiu et al. 2020; *USEPA 1994, **PAAS

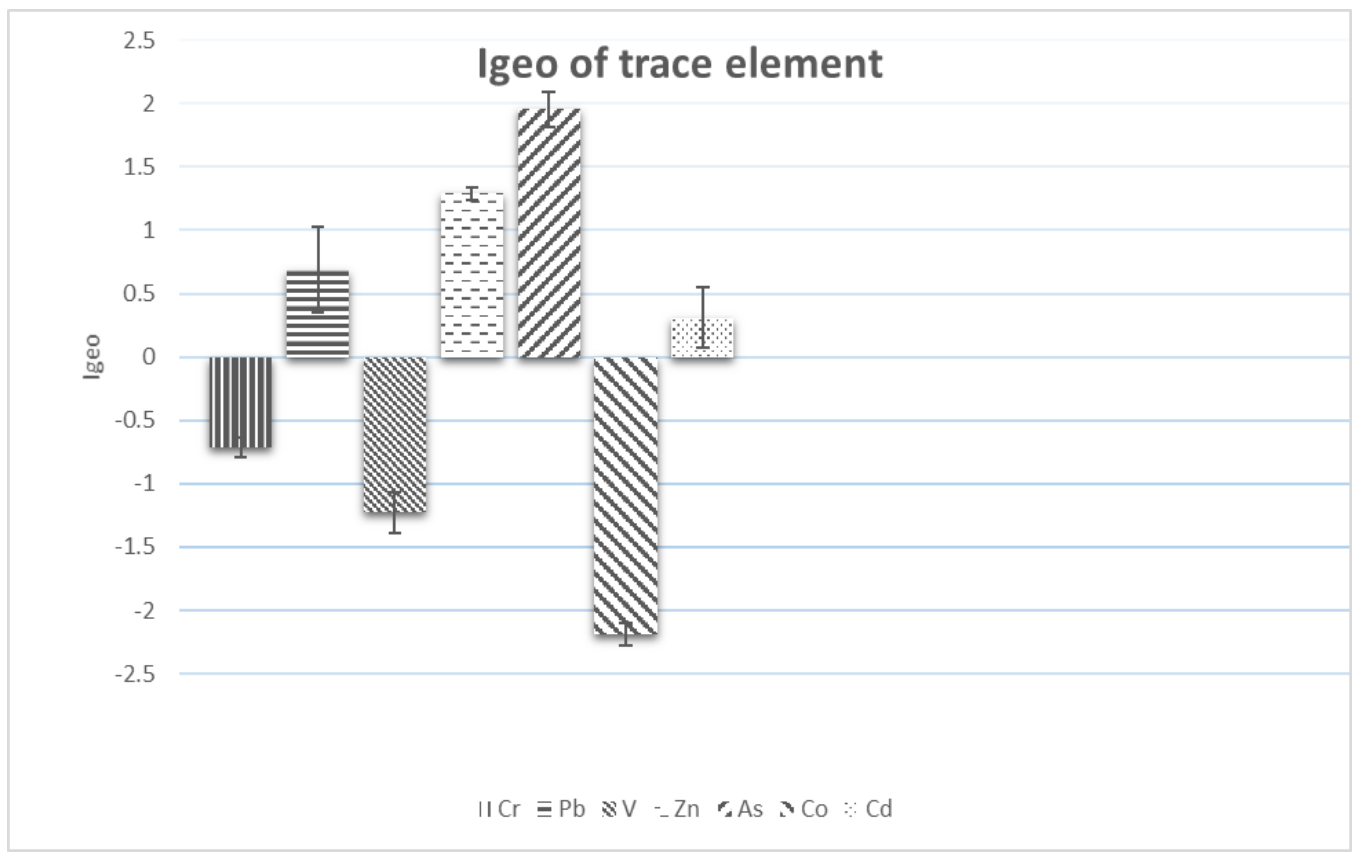

Figure 2 Geo-accumulation index (Igeo) of the elements in the sediment

Journal of Experimental Biology and Agricultural Sciences http://www.jebas.org 
The Igeo, EF, CF, and PLI of As, Cd, Cr, V, Pb, Zn, and Co in the sediment samples are shown in Figure 2, Figure 3, and Figure 4 respectively. The lowest EF (0.45) was found for the Co while the highest (7.96) for the As. Most of the trace elements showed higher $\mathrm{EF}$ values except for $\mathrm{Co}$ and $\mathrm{V}$. The EF value of the studied location, Juru indicates minor to moderately severe enrichment of $\mathrm{Cd}, \mathrm{Pb}, \mathrm{Zn}$, and As. Based on the $I_{\text {geo }}$ index as shown in Figure 3, the lowest Igeo found was $-2.18(\mathrm{Co})$ and the highest 1.95 (As). The EF of As and $\mathrm{Zn}$ of the current study is about the same as reported by another study 7.3 and 6.6 respectively (Yii et al. 2020). Most of the trace elements fall in class 0 and 1 are defined as unpolluted and unpolluted to moderately polluted respectively, except for As and $\mathrm{Zn}$ which are 1.95 and 1.29 respectively. The CF and PLI were used to assess the status of the heavy metals in sediments (Bhuiyan et al. 2010). Like other parameters, the lowest $\mathrm{CF}$ was found 0.33 for Co and the highest 5.83 for As. The $\mathrm{Cr}$, V, and Co showed low contamination. The $\mathrm{Pb}$ and $\mathrm{Cd}$ reach moderate contamination. The computed mean value of PLI exceeds the unit (PLI > 1).

It was found that all pollution tools $(\mathrm{EF}$, Igeo $\mathrm{CF}$, and PLI) indicate sediments from mangrove areas, Juru river contaminated with As and $\mathrm{Zn}$ compared other trace constituents in this work. Special

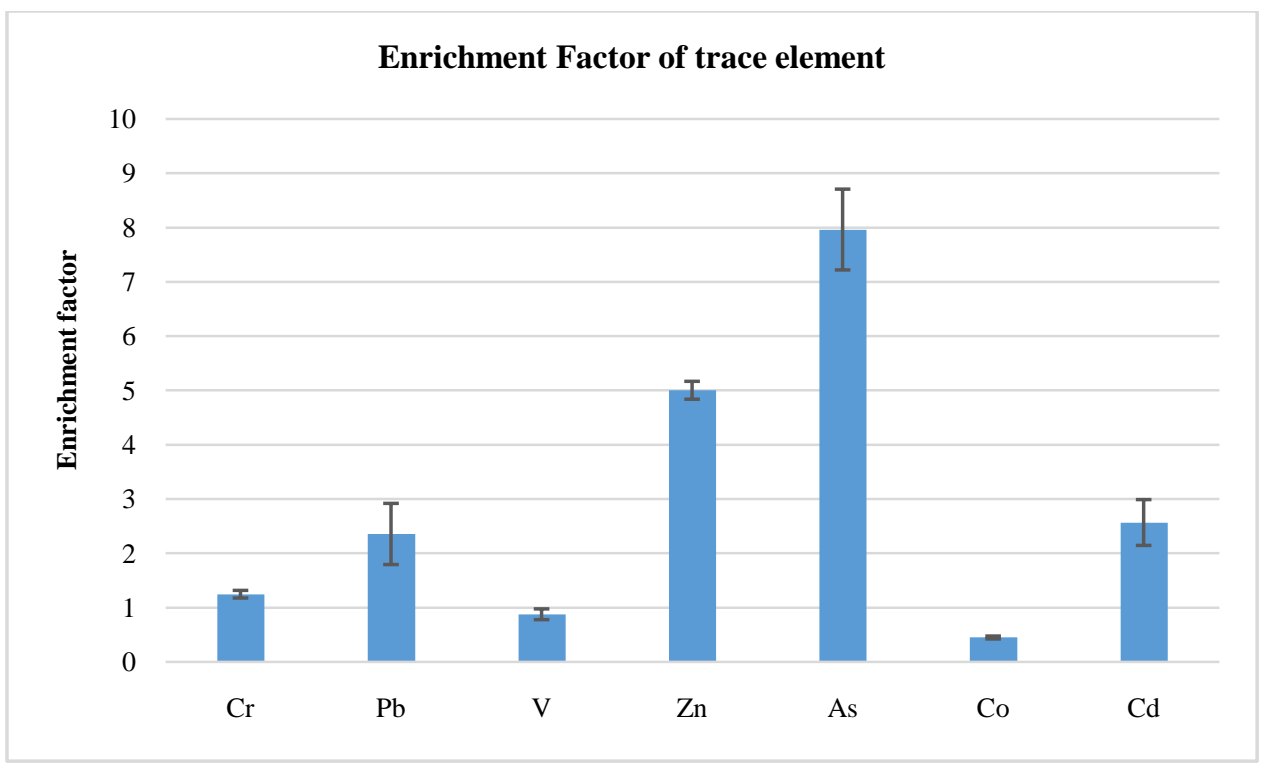

Figure 3 Enrichment Factor (EF) of the trace elements in the sediment

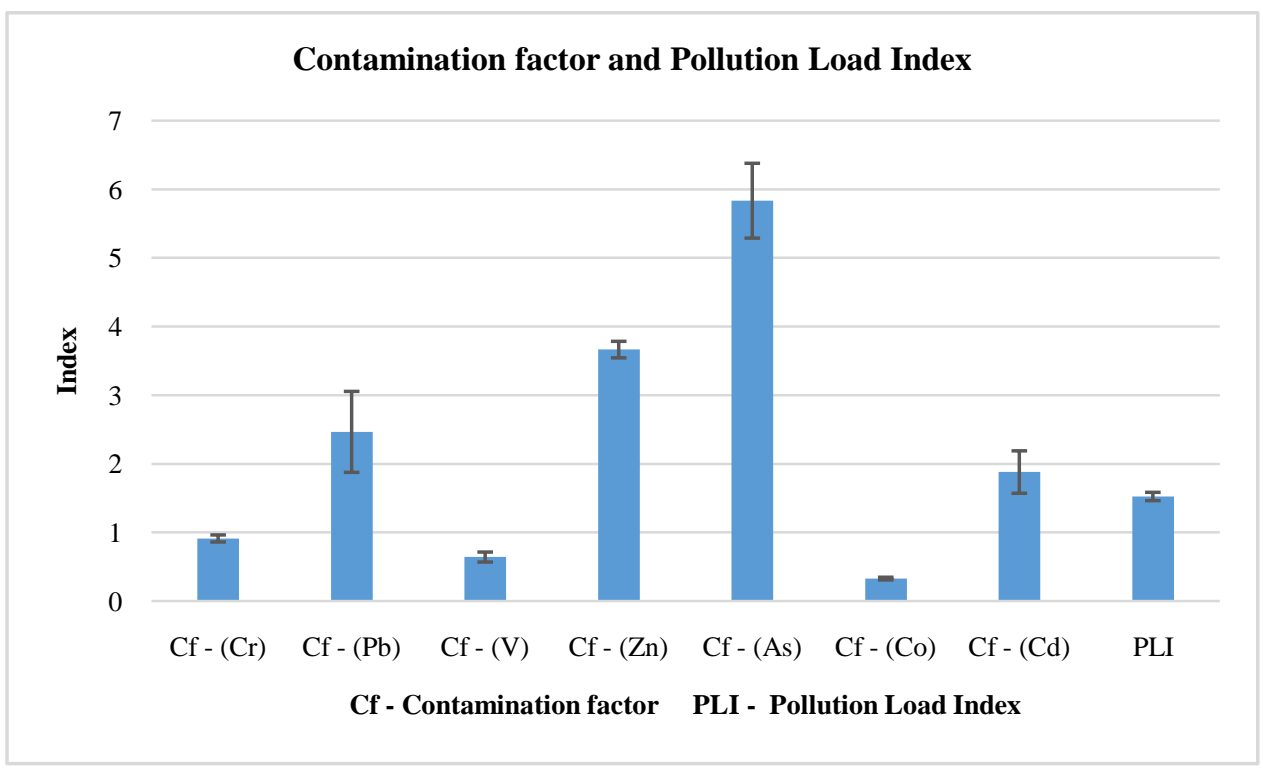

Figure 4 Contamination factor (Cf) and Pollution Load Index (PLI) of the elements in the sediment 
consideration needs to be given to As and $\mathrm{Zn}$ for their mobility and bioavailability in the aquatic ecosystem. The highest enrichment factor (EF) is mostly due to anthropogenic sources of heavy metals, such as waste disposal, industrialization, urbanization, and others (Gao et al. 2020). This could occur as a result of untreated industrial, residential, and agricultural waste products (Talukder et al. 2021; Jahan and Strezov 2018). As reported by other studies, these could be due to the Juru River receiving a discharge of waste product from several small rivers that flow through urban areas which are active with human activities and originated from non-natural weathering processes or non-crustal materials caused by anthropogenic sources (Yap et al. 2009; Valiela et al. 2002). On the other hand, other activities such as loading and unloading fish from the fisherman and cleaning of boats and maintenance may be also contributing enrichment factors is higher than other sampling locations. Human activities such as tourism, agriculture, aquaculture, and urban sprawl are the main drivers linked to the destruction of mangrove areas. Uneaten fish feed, fish waste, and any organic material that is produced by fish farming activities also destroyed mangrove areas and vary between regions (Al-Shami et al. 2011). There are approximately 300 local fishermen who depend on fish and shellfish catches in rivers and estuaries who are worried about the potential impact on the environment following the implementation of shrimp farming projects in the area near the river Juru (Press Statement, 9 October 2012).

\section{Conclusions}

Juru mangrove sediments were found to be significantly impacted by toxic levels of trace metals ( $\mathrm{Zn}$ and $\mathrm{Pb}$ ) above the EPA standard. The EF and Igeo values indicate that sediments of mangrove Juru river severely contaminated with As and $\mathrm{Zn}$. The continued discharges of abandoned metals components and effluents from industrial and commercial activities along the Juru River, such as fishing (nets, hooks, etc.), shipping, lumber processing, and outboard engine boats, may have increased the possibility of these metals (As and $\mathrm{Zn}$ ). As a result, there are serious environmental issues when a bioavailable proportion of hazardous materials directly damages estuarine fish and other biota by incorporating them into the food chain. This study thus provides baseline information on metal concentration and anthropogenic impacts on mangrove forests of Juru and requires the continuous monitoring.

\section{Acknowledgements}

The authors wish to acknowledge the financial support via the Research Grant Scheme (Seed Grant no:INTI-FITS-02-072018/19) provided by INTI International University, Nilai, Malaysia.

\section{Conflict of Interest}

Nil

\section{References}

Abrahim, G.M.S., \& Parker, R.J. (2008). Assessment of Heavy Metal Enrichment Factors and the Degree of Contamination in Marine Sediments from Tamaki Estuary, Auckland, New Zealand. Environmental Monitoring and Assessment, 136, 227-238.

Affandi, F.A., \& Ishak, M.Y. (2018). Heavy metal concentrations in tin mine effluents in Kepayang River, Perak, Malaysia. Journal of Physical Science, 29(3), 81-86.

Alfian, Yusuf, S., \& Sutisna (2020). Elemental analysis of SRM 1547 peach leaves, 1573a tomato leaves, and 1570a spinach leaves. Journal of Physics: Conference Series, 1436, 012044.

Alnour, I.A., Ibrahim, N., \& Fen, L.H. (2011). The accuracy of the absolute NAA method based on theanalysis of standard reference materials (SRMs). International Journal of the Physical Sciences, 6(17), 4169-4175.

Al-Shami, S.A., Md Rawi, C.S., Ahmad, A.H., Abdul, H.S., \& Mohd Nor S.A. (2011). Influence of agricultural, industrial, and anthropogenic stresseson the distribution and diversity of macroinvertebrates in Juru River Basin, Malaysia. Ecotoxicology and Environmental Safety, 74(5), 1195-1202.

Ashraf, A., Saion, E., Gharibshahi, E., Kamari, H.M., et al. (2016). Rare earth elements in core marine sediments of coastal East Malaysia by instrumental neutron activation analysis. Applied Radiation and Isotopes, 107, 17-23.

Benarfa, A., Begaa, S., Messaoudi, M., Hamlat, N., \& Sawicka, B. (2020). Elemental composition analysis of Pistacia lentiscus L., leaves collected from Mitidja plain in Algeria using instrumental neutron activation analysis (INAA) technique. Radiochim. Acta, 108, 821; https://doi.org/10.1515/ract-2020-0011.

Bhuiyan, M.A.H., Parvez, L., Islam, M.A., Dampare, S.B., \& Suzuki, S. (2010). Heavy metal pollution of coal mine-affected agricultural soils in the northern part of Bangladesh. Journal of Hazardous Materials, 173, 384-392.

Brügmann, L., Kremling, K., Grasshoff, K., Kremling, K., Ehrhardt, M. (1999). Sampling in methods of seawater analysis. In: Grasshoff, K., Kremling, K., \& Ehrhardt, M. (Eds.), 3rd edn. Wiley, Weinheim. https ://doi./10.1002/97835 27613 984.ch1.

Cabrera, F., Clemente, L., Barrientos, D.E., López, R., \& Murillo, J.M. (1999). Heavy metal pollution of soils affected by the 
Guadiamar toxic flood. Science of The Total Environment, 242, 117-129.

Carvalho, P.R., Munita, C.S., Neves, E.G., \& Zimpel, C.A. (2019). Chemical characterization of ancient pottery from the south-west Amazonia using instrumental neutron activation analysis. Brazilian Journal of Radiation Sciences, 7, 1-14.

Chai, H.P., Lee, N., Grinang, J., Ling, T.Y., \& Sim, S.F. (2018). Assessment of heavy metals in water, fish and sediments of the Baleh River, Sarawak, Malaysia. Borneo Journal of Resource Science and Technology, 8(1), 30-40.

Chen, H., Teng, Y., Li, J., Wu, J., \& Wang, J. (2016). Source apportionment of trace metals in river sediments: A comparison of three methods. Environmental Pollution, 211, 28-37.

Diarra, I., \& Prasad, S. (2020). The current state of heavy metal pollution in Pacific Island Countries: a review. Applied Spectroscopy Reviews, 56(1), 1-25. https://doi.org/10.1080/ 05704928.2020.1719130.

Diop, C., Dewaelé, D., Cazier, F., Diouf, A., Ouddane, B. (2015). Assessment of trace metals contamination level, bioavailability and toxicity in sediments from Dakar coast and Saint Louis estuary in Senegal, West Africa. Chemosphere, 138, 980-987.

Friess, D.A., Rogers, K., Lovelock, C.E., Krauss, K.W., Hamilton, S.E., \& Lee, S.Y. (2019) The State of the World's Mangrove Forests: Past, Present, and Future. Annual Review of Environment and Resources, 44, 89-115. doi:10.1146/annurev-environ-101718033302

Gao, X., Arthur Chen, C.T., Wang, G., Xue, Q., Tang, C., Chen, S. (2010) Environmental status of Daya Bay surface sediments inferred from a sequential extraction technique. Estuarine, Coastal and Shelf Science, 86 (3), 369-378.

Ghannem, S., Khazri, A., Sellami, B., \& Boumaiza, M. (2016). Assessment of heavy metal contamination in soil and Chlaenius (Chlaeniellus) olivieri (Coleoptera, Carabidae) in the vicinity of a textile factory near Ras Jbel (Bizerte, Tunisia). Environmental Earth Sciences, 75, 442.

Hakanson, L. (1980). An ecological risk index for aquatic pollution control. A sedimentological approach. Water Research, 14(8), 9751001.

Hatje, V., Masqué, P., Patire, V.F., Dórea, A., \& Barros, F. (2020). Blue Carbon Stocks, Accumulation Rates, and Associated Spatial Variability in Brazilian Mangroves. Limnology and Oceanography, 1, 1-14. doi:10.1002/1no.11607
Jahan, S., \& Strezov, V. (2018). Comparison of pollutionindices for the assessment of heavy metals in the sedi-ments of seaports of NSW. Marine Pollution Bulletin, 128, 295-306.

Kadhum, S.A., Ishak, M.Y., \& Zulkifli, S.Z. (2015). Evaluation of the status and distributions of heavy metal pollution in surface sediments of the Langat River Basin in Selangor, Malaysia. Marine Pollution Bulletin, 101(1), 391-396.

Khalaf, B., Abdullah, M.P., \& Tahrim, N.A. (2018). Detection of heavy metals in water in Negeri Sembilan, Malaysia: From source to consumption. AIP Conference Proceedings, 1940(1), 020107.

Kumar, K., Saion, E., Halimah, M., Yap, C., \& Hamzah, M.S. (2014). Rare earth element (REE) in surface mangrove sediment by instrumental neutron activation analysis. Journal of Radioanalytical and Nuclear Chemistry, 301(3), 667-676.

Li, Y., Gou, X., Wang, G., Zhang, Q., Su, Q., \& Xiao, G. (2008). Heavy metal contamination andsource in arid agricultural soils in central Gansu Province, China. Journal of Environmental Sciences, 20,607-612.

Malsiu, A., Shehu, I., Stafilov, T., \& Faiku, F. (2020). Assessment of Heavy Metal Concentrations with Fractionation Method in Sediments and Waters of the Badovci Lake (Kosovo). Journal of Environmental and Public Health, 3098594, 1-14.

Mucha, A.P., Vasconcelos, M., \& Bordalo, A.A. (2003). Macrobenthic community in the Douroestuary: relat ions with trace metals and natural sediment characteristics. Environmental Pollution, 121, 169-180

Muller, G. (1969). Index of geoaccumulation in sediments of the Rhine River. Geojournal, 2, 108-118.

Naser, H.A. (2013). Assessment and management of heavy metal pollution in the marine environment of the Arabian Gulf: a review. Marine Pollution Bulletin, 72(1), 6-13.

Nasr, S.M., Okbah, M.A., \& Kasem, S.M. (2006). Environmental assessment of heavy metal pollution in bottom sediment of Aden port, Yemen. International Journal of Oceanography, 1(1), 99109.

Othman, F., Uddin Chowdhury, M., Jaafar, W., Zurina, W., Mohammad Faresh, E.M., \& Shirazi, S.M. (2018). Assessing risk and sources of heavy metals in a tropical river basin: A case study of the Selangor River, Malaysia. Polish Journal of Environmental Studies, 27(4), 1659-1671. 
Press Statement (2012). Press Statement 9 October 2012. Retrived from https://consumer.org.my/do-not-let-juru-river-die-frompollution/

Rezaee, K., Abdi, M., Saion, E., Naghavi, K., \& Shafaei, M. (2011). Distribution of trace elements in the marine sediments along the South China Sea, Malaysia. Journal of Radioanalytical and Nuclear Chemistry, 287(3), 733-740.

Sasmito, Kuzyakov, Y., Lubis, A.A., Murdiyarso, D., et al. (2020). Organic carbon burial and sources in soils of coastal mudflat and mangrove ecosystems. Catena, 187, 104414 10.1016/j.catena.2019.104414.

Stoffers, P., Glasby, G., Wilson, C., Davis, K., \& Walter, P. (1986). Heavy metal pollution in Wellington Harbour. New Zealand. Journal of Marine and Freshwater Research, 20(3), 495512 .

Sukri, N.S., Aspin, S.A., Kamarulzaman, N.L., Jaafar, N.F., et al. (2018). Assessment of metal pollution using enrichment factor (EF) and pollution load index (PLI) in sediments of selected Terengganu Rivers, Malaysia. Malaysian Journal of Fundamental and Applied Sciences, 14(2), 235-240.

Tair, R., \& Eduin, S. (2018). Heavy metals in water and sediment from Liwagu River and Mansahaban River at Ranau Sabah. Malaysian Journal of Geosciences, 2(2), 26-32.

Talukder, R., Rabbi, M.H., Baharim, N.B., \& Carnicelli, S. (2021). Source identification and ecological risk assessment of heavy metal pollution in sediments of Setiu wetland, Malaysia Environ Forensics, https://doi.org/10.1080/15275922.2021.1892871.

Tiwari, M., Sahu, S.K., Rathod, T.D., Bhangare, R.C., Ajmal, P.Y., \& Vinod Kumar, A. (2020). Determination of trace elements in salt and seawater samples by energy dispersive X-ray fluorescence spectrometry. Journal of Radioanalytical and Nuclear Chemistry, 325, 751-756. https://doi.org/10.1007/s10967-020-07187-5

Tomlinson, D.L., Wilson, J.G., Harris, C.R., \& Jeffrey, D.W (1980). Problems in the assessment of heavy metal levels in estuaries and the formation of a pollution index. Helgol Meeresunter, 33(1-4), 566-575.

Turekian, K.K., \& Wedepohl, K.H. (1961). Distribution of the elements in some major units of the earth's crust. Geological Society of America Bulletin, 72(2), 175-192

United States Environmental Protection Agency, Method 200.8. (1994). Determination of trace elements in waters and wastes by inductively coupled plasma-Mass Spectrometry. Retrived from https://www.epa.gov/sites/produ-ction/files-/2015-08/documents/ method_200-8_rev_5-4_1994.pdf (accessed October 2017)

Valiela, I., Bowen, J.L., \& Kroeger, K.D. (2002). Assessment of models for estimation of land-derived nitrogen loads to shallow estuaries. Applied Geochemistry, 17(7), 935-953.

Veettil, B.K., Ward R.D., Quang, N.X., Trang, N.T.T, \& Giang, T.H. (2019). Mangroves of Vietnam: Historical Development, Current State of Research and Future Threats. Estuarine, Coastal and Shelf Science, 218, 212-236. doi:10.1016/j.ecss.2018.12.021

Wang, H., Wang, J., Liu, R., Yu, W., \& Shen, Z. (2015). Spatial variation, environmental risk and biological hazard assessment of heavy metals in surface sediments of the Yangtze River estuary. Marine Pollution Bulletin, 93, 250-258.

Wang, S., Jia, Y., Wang, S., Wang, X., Wang, H., Zhao, Z., \& Liu, B. (2010). Fractionation of heavy metals in shallow marine sediments from Jinzhou Bay, China. Journal of Environmental Sciences, 22(1), 23-31.

Win, D.T. (2004). Neutron Activation Analysis (NAA). Faculty of Science and Technology, Assumption University Bangkok, Thailand. Au Journal of Technology, 8(1), 8-14.

Yap, C., Ismail, A., Tan, S., \& Omar, H. (2002). Concentrations of $\mathrm{Cu}$ and $\mathrm{Pb}$ in the offshore and intertidal sediments of the west coast of Peninsular Malaysia. Environment International, 28(6), 467479.

Yap, C.K., Cheng, W.H., Ismail, A., Rahim Ismail, A., Tan, S.G. (2009). Biomonitoring of heavy metal concentrations in the intertidal area of Peninsular Malaysia by using Nerita lineata. Toxicological and Environmental Chemistry, 91(1), 29-41.

Yii, M.W., Zal, W.M., Elias M.S., \& Yusof (2020). The distribution of heavy metals and natural radionuclides within the surface sediments of the Juru River. AIP Conference Proceedings, 2295, 020006; https://doi.org/10.1063/5.0031493.

Yunus, K., \& Chuan, O.M. (2008). Distribution of Some Geochemical Elements in the Surface Sediment of Kerteh, Mangrove Forest, Terengganu, Malaysia. Sains Malaysiana, 37, $337-340$.

Yunus, K., Nurullnadia, M.Y., Chuan, O.M., Shahbudin, S., et al. (2011). Heavy Metal Concentration in the Surface Sediment of Tanjung Lumpur, Mangrove Forest, Kuantan, Malaysia. Sains Malaysiana, 40(2), 89-92.

Yunus, K., Zuraidah, M. A., \& John, A. (2020). A review on the accumulation of heavy metals in coastal sediment of Peninsular 
Malaysia. Ecofemininism Climate Change, 1, 21-35. DOI 10.1108/EFCC-03-2020-0003.

Zarei, I., Pourkhabbaz, A., \& Khuzestani, R.B. (2014). An assessment of metal contamination risk in sediments of Hara Biosphere Reserve, southern Iran with a focus on application of pollution indicators. Environmental Monitoring and Assessment, 186(10), 6047-6060.
Zhang, Y., Guo, F., Meng, W., \& Wang, X.Q. (2009). Water quality assessment and source identification of Daliao river basin using multivariate statistical methods. Environmental Monitoring and Assessment, 152(1-4), 105

Zoller, W.H., Gladney, E.S., \& Duce, R.A. (1974). Atmospheric concentrations and sourcesof trace metals at the South Pole. Science, 183, 198-200. 